\title{
Wardrobe in Chain: Societal Dominance in Guise of Clothing Female Body
}

\author{
Ananya Guha Roy \\ Assistant Professor Dept. of Political Science, Saheed Kshudiram College, Kamakhyaguri
}

\begin{abstract}
India is that country in this vast world which has even gone to the length of worshipping her women as living images of the divine. For this reason, India is known as 'Mother India'. However, women's vulnerability to violence is increasingly seen as linked to women's lack of voice in political governance as well as legal empowerment and access to justice. Despite several legislative measures adopted in favour of women, during recent years, countless women continue to be victims of discrimination and gender-specific violence. According to the report given by National Crime Record Bureau India, women's vulnerability to sexual atrocities (rape) has increased from 2487 cases in 1971 to 33707 cases in 2013 which is higher than most other leading crimes in India. Surprisingly many have blamed the women herself is the probable cause that led to such heinous crime. Women are often judged on the basis of the way they dressed themselves up. Clothing always has had an outstanding role in revealing the individual's desire for self-expression alongside an important medium of exercising control over the bodies. What a woman wears marks her as a "good" or a "bad" woman in the society.
\end{abstract}

This paper attempts to discuss the debatable issue of the responsibility of the women at this crucial situation. Moreover, it tries to address the question is how far the women can be compelled for wearing a 'decent' cloth? Or even, can a 'cloth' be classified as 'decent' or 'indecent'? Or does 'decent' clothing ensure women's security? If yes, then why are the nuns or the Muslim women in burqa getting raped? This present paper tries to focus the issue of clothing as well as the growing anxieties regarding it.

Keywords: Atrocity, Clothing, Discrimination, Gender, Indecent, Violence.

\section{INTRODUCTION}

For ages society had differentiated between male and female. Male enjoyed all sorts of rights in society and female had only duties, no rights. As women were considered as the weaker sex so they were confined to the private sphere of home and family. The domains of men were defined as 'public', enabling them to enjoy power and the democratic rights. Women were supposed to perform domestic work and to bear children. Men's world was that of production; women's world was that of re-production. In the male-dominated world women had always been considered as inferior, less competent, less valuable and therefore they had been subjected to discrimination and deprivation from all spheres - social, economic, political and cultural. According to Bharati Roy, "a male sphere of public life was supposed to be one of prestige and power, a female sphere was private and not public and it was a life of degradation and confinement." The feminist movement wants to treat every individual not on the basis of sex but as a human being. There should be gender-equality everywhere. The feminist movement attempts to establish the right of women, to improve their standard of living, to spread education among them and to empower them so that they can achieve self-reliance and selfconfidence that would help them to play an equal role with men in all the fields.

Several international human rights organisations have been advocating, promoting and protecting the rights of women from the middle of the 20th century. In India, The State Human Rights Commission has been set up to protect the rights not only of men but also of women and children. In addition, the National Women's Commission has been constituted to look into cases of injustice and violence towards women. In 1979, the UN General Assembly adopted the convention for the Elimination of all forms of Discrimination against Women (CEDAW). In India in 1987, the 'Indecent Representation of Women (Prohibition) Act' was passed to prohibit indecent representation of women through advertisements. Protection of Women from Domestic Violence Act, 2005 and the Compulsory 
Registration Marriage Act, 2006 has been enacted to emancipate women in India. It has been categorically stated that anything that makes a women feel inferior and takes away her self-respect is to be regarded as abuse. But in spite of all these developments the hard reality of gender-disparity is still very much present in the Indian society.

\section{OBJECTIVES OF THE STUDY}

Despite several legislative measures adopted in favour of women, during recent years, countless women continue to be victims of discrimination and gender-specific violence. According to the report given by National Crime Record Bureau India, women's vulnerability to sexual atrocities (rape) has increased from 2487 cases in 1971 to 33707 cases in 2013 which is higher than most other leading crimes in India. Surprisingly many have blamed the women herself is the probable cause that led to such heinous crime. Women are often judged on the basis of the way they dressed themselves up. This paper attempts to discuss the debatable issue of the responsibility of the women at this crucial situation. Moreover, it tries to address the question is how far the women can be compelled for wearing a 'decent' cloth? Or even, can a 'cloth' be classified as 'decent' or 'indecent'? Or does 'decent' clothing ensure women's security? If yes, then why are the nuns or the Muslim women in burqa getting raped? This present paper tries to focus the issue of clothing as well as the growing anxieties regarding it.

\section{Methodology}

The study is primarily descriptive in nature. For this study, secondary sources are used and examined. The findings of other scholarly studies on the same problem have also been taken into account. Different journals and the newspapers are considered as a source of data.

\section{DiscuSSION AND ANALYSIS}

In the patriarchal society men dominated over women in every sphere of life. Women were considered as inferior to men in all respects. According to Shoma Chatterji, "Patriarchy and Capitalism operate effectively together to use women as a profitable source of production and reproduction while keeping control over women's labour and perpetuating their inferior status". In Indian culture, masculine roles have traditionally been associated with strength, aggression, and dominance, while feminine roles have traditionally been associated with passivity, nurturing, and subordination. The socialization process in which children learn these gender roles begins at birth. Children learn at a young age that there are distinct expectations for them based on their assigned gender. Cross-cultural studies reveal that children are aware of gender roles by age two or three; at four or five, most children are firmly entrenched in culturally appropriate gender roles. Parents often supply male children with trucks, toy guns, and superhero paraphernalia, which are active toys that promote motor skills, aggression, and solitary play. Female children are often given dolls and dress-up apparel that foster nurturing, social proximity, and role play. Studies have shown that children will most likely choose to play with "gender appropriate" toys even when cross-gender toys are available. So from the very childhood the surroundings try to mould our coming future according to our gender.

\section{DECENT VS. INDECENT}

Identity and dress are intimately linked. Clothes display, express and shape identity, imbuing it with a directly material reality. They thus offer a useful lens through which to explore the possibly changing ways in which older identities are constituted in modern culture. The focus is on clothing and dress rather than fashion. From the time Veblen (1889) and Simmel (1904) onwards sociologists have explored the way in which clothing operates as part of class identity, with fashions diffusing down the social hierarchy as they are successively adopted and abandoned by elites, and as lower groups take up the style. Bourdieu (1984) refined the account with analysis of the role of clothing as a marker of class distinction in which dress is an aspect of cultural capital, part of how elites establish, maintain and reproduce positions of power, reinforcing relation of dominance and subordination. Gender has always been played the most significant role in the entire issue. Indeed theorists like Entwistle (2000) present fashion as essentially preoccupied with gender. Clothes have long been used to hide sexual difference in its strong biological sense, at the same time to pointing up and signalling it through assumptions concerning gender in clothing codes. Fashion thus helps to reproduce gender as a form of body style, producing a complex interplay between sexed bodies and gendered identities. Davis (1992) and Tseelon (1995) similarly regard the ambivalences of gender as at the heart of fashion. 
Much of the writing on gender and fashion has been rooted in feminist's analysis. Feminists of the second wave tended to be critical of the fashion system and its malignant impact on the lives of women. Fashion was seen as imposing oppressive forms of gender identity, embodying practices designed to objectify and limit women, locking them into defensive and inauthentic forms of presentation, and reinforcing their cultural association with narcissism and triviality. More recently, feminists influenced by post- modernism, have taken a less negative view, recognising the inescapability of matters of style and cultural formation in relation to the body and appearance. They have been willing to see fashion as part of a distinctive women's culture, an area of pleasure and expressivity that goes beyond the reproduction of patriarchy and capitalism (Wilson 1985, Evans and Thornton 1989).

In today's world, decency is a very serious issue. The term "decency" has always been a matter of controversy and there is always a political dimension to define it. Without being purely relativistic, we want to point out that decency is a loaded concept, it has political implications and it cannot be radically divorced from power and the hierarchies through which it is instituted. Clothing is presented as a linguistic code - a means whereby people send messages about themselves. But it is an inexact one, because the intention of the wearer and the interpretation of the observer are not always same. So very often the code communicates ambiguity and complexity. Dress is closely linked to the body. It envelops the body and presents it to the social world. It is the body that makes clothes alive. Over the last two decades there has been a mass of writing on the body as well as the dress. Take the example of Miniskirt, a fashionable outfit that arose in the sixties. Although seen as a trendy clothing item that has empowered women to own their bodies and to be proud of their sexuality, it can also be viewed as a mechanism through which men can define the female body. Most obviously, the miniskirt has contributed to the sexualisation of legs as well as the male visualisation of the female body over decades. This varies the question of whether clothing is a feminist tool. Clothing is always been seen as a tool of empowerment, allowing people to express themselves.

\section{Societal Dominance}

According to Christian belief, our clothing was invented by God to cover our bodies. It is appropriate to understand the purpose for clothing. If we grasp why God desires us to be clothed, then conversely we will understand why the increasing trend of 'lack of clothing' is criticised. Originally the first man and woman, Adam and Eve, did not need clothing because they were 'not ashamed'. They had not violated any of God's holiness by sinning. There was no lust, no immorality, and no lewdness. The human body was the perfect creation of God. Christianity believes that after Adam and Eve chose to sin and disobeyed God, that perfect holiness was lost and sense of shame came upon them. So from that point on, their bodies were now a source of shame because they were no longer in perfect fellowship and holiness with their Creator God. So Adam and Eve took large leaves, sewed them together and covered themselves. Christianity opines that modesty only starts with what clothes you wear. It is an attitude of the heart, a statement of holiness about your entire life; and a part of being a 'living sacrifice', pleasing and acceptable to God.

In ancient India the women's clothing was no less debatable. The three portion of the cloth did not conceal the abdomen of the women's body as it was symbolical of the respect showed to the motherhood. It may be taken as the case of the spoken or unspoken rules that are laid down by the traditional hierarchical society and are expected to follow by the members of it. However, during the 19th century when the westernisation of Indian society brought petticoat, blouse and shoes for the women, the very items which are now considered as a primary essentials, were not accepted. They were considered to be vulgar and corrupting for women even though they covered the body far better than the single length sari. Women education in India plays a vital role in the overall development of the country. Contrary to common perception, a large percentage of women in India are working today. They now participate in areas such as education, sports, politics, media, art and culture, service sector, science and technology. But due to the deep-rooted patriarchal mentality in the Indian society, women are still victimised, humiliated, tortured and exploited.

Clothing of a woman here is also dependant on the group or ethnic community that she belongs to. Here a woman who is not working outside is expected to adhere to the older norms of clothing, but the women who work outside enjoy comparatively better freedom in terms of clothing. That may also differ according to the demands of the sectors in which they work in. In the Indian culture women are very fond of wearing salwar-kameez or churidar-kurta in the occasional purpose as well as in the daily 
use. The wearing of a 'dupatta' is perhaps the most carefully calibrated act of everyday dressing in contemporary India. Also called 'chunari' or 'odhni' in North India, the 'dupatta' is understtod to be a necessary accessory to the salwar-kameez, churidar-kurta or ghagra-choli. So much so that the coordinated salwar-kameez sets that are probably the most ubiquitous women's wear in India- come with matching 'dupattas'. But, there are certain styles of salwar-kameez that do not need dupatta, for instance, the indo-western pattern of salwar-kameez does not require one. But the 'dupatta' quietly inserts itself into one's idea of the outfit in that extent that if you wear a 'suit', you automatically wear the 'dupatta' that comes with it. It's not wearing a 'dupatta' that is then marked out as an act of choice. Even when a 'dupatta' is worn, though, there is always the complicated question of how. In more orthodox households, women still drape their 'dupattas' or 'pallus' (of the saris) to cover their heads and faces before men other than their husbands. But while the practice of 'purdah' is probably less common, the 'dupatta' does not look like it's going away anytime soon. However it's draped, though, the primary purpose of this unstitched length of fabric appears to be to cover up anything a woman's stitched garments may reveal - whether the possibility of cleavage or just the possibility of breasts. So sometimes the 'dupatta' is a must to police their bodies.

When men in our country harass women, it has more to do with their mentality than the woman herself. If a woman is not wearing a dupatta, she is not "asking for it". This is exactly what lays the foundation for the prevalent rape culture that automatically views rape and any form of harassment as a reaction to some act of the woman herself. Society makes women feel like they are at fault. Even Mukesh Singh, the bus-driver of the Delhi gang rape (in the 'nirbhaya' case) said that, "A girl is far more responsible for rape than a boy ..........A boy and a girl is not equal. House work and housekeeping is for girls, not roaming in discos and bars at night doing wrong thing, wearing wrong clothes." Perhaps, their biggest error is being a woman in our backward and primitive society that sees choices of women merely in the context of 'modern' or 'chic'. It is significant for us to remember that the dupatta is just a piece of cloth. It does not carry anyone's honour or izzat. It has no special powers to protect a woman. It is merely a piece of cloth that has disappeared from fashion spreads in magazines.

If a dupatta was all it took to end harassment in this country, men would be eager to embody it too. But the subject of harassment extends beyond the fabric of a dupatta. It is intricately bound to female subjugation, patriarchy, objectification and how our society views women. No matter how much cloth we add on to a woman's body, she still faces and endures harassment in all spheres. Moreover even when you cover yourself fully with dupatta, people with wrong intention still stare at those parts covered by dupatta, while people without wrong intentions won't care even if you walk half-naked. It's not in clothes; it's all in our mind.

]Have we forgotten the video of that woman, in a burqua and niqab, who was harassed on Independence Day in Pakistan? Beyond the 'wear more clothes' argument, they will say, 'do not go out. Do not leave your house'. But, is there any such precedent that states that woman do not get harassed in their own households? Surely not. Our women believe that whenever they are harassed, it has to have been their own fault. We manage to turn our women and their freedom to wear whatever clothing they choose, into an exhaustive debate riddle with 'false' concepts regarding women empowerment and the aesthetics of a progressive society. Every time any woman propagates her right to decide what she wears and what she does not, we lament her in the name of the ideology of feminism or women empowerment.

A woman may select a dress, but that may conflict with the interest of others. In such cases the motive of the wearer becomes important. Depending on the motive of the wearer, even the most traditional dress, such as sari can be worn in an indecent way, where as a western outfit can be far more decent. Girls who do not wear dupatta with salwar suit are not shameless. Shamelessness is not determined by your clothing rather determined by your deeds. Shame is in the eyes of the beholder not in the clothes you wear. You might be wearing a sari. Your waist would be clearly seen. And left side bust is also clearly visible from the left side. It might be covered from the front but when you lift your left hand front, someone can clearly see your waist and left bust. If your blouse is little tight then full shape also clearly visible. I have seen women like these telling proudly that they are very cultured like you. Sari is more cultured than salwar kameez inclusive of dupatta. Unless someone is provocatively dressed then there is nothing to be shameful of. We are not hiding our bodies; we are dressing them up even more neatly. 
We need to rid ourselves of these apologetic attitudes with the hopes of coming across as more 'cultured'. We really need to quit focusing on what clothing women choose to wear, and spend a little more time raising our boys to not objectify women. Clothes do not determine your shame, culture, and ethics at all. Different patterns, different styles exist because we as individuals are different. Why do you want someone to be confined in the boundaries of moral policing and why only one dressing style! Wear what suits you, interests you, fit your body type. The practice of clothing has evolved only with civilization. Otherwise people barely use to wear any clothing.

\section{CONCLUSION}

Fashion is very person specific. It depends on what you are comfortable in and not the moral policing or right/wrong, shameful/shameless, etc. I write this piece in the hope for more power to the women and less to the dupatta. It's a matter of personal choice and willingness to experiment with their choice of style. Every person has to exercise that and we shouldn't have a problem with that. At least being a woman, who knows how an Indian woman is suppressed by all the dimensions of the society.

The cloth itself cannot be categorised simply as moral or immoral, it is rather a means of the motive which can be moral or immoral. Moreover as the campaigns by Times of India shows the sexual atrocities on woman is no less in the rural area where women generally wear the most traditional dresses than in the urban India. So the hypothesis that women's revealing clothing is the sole reason behind their violent victimisation becomes not true at all. Clothing is never interpretive of a woman's moral virtue: if it is so it should be applicable both in the cases of men and women, it should never be one way agenda. Moreover, no woman ever will want to engage an unwanted or immoral interest which may cause her harm. It is an established fact that to harm other violently is a serious moral and legal offence, and in no way should a victimised woman be blamed for the immoral activities of others. So it is clear that the attempt of the present day Indian society is not only to judge the women in terms of their clothing, but rather to control their clothing.

\section{REFERENCES}

[1] Bharati Roy (ed.) Women and Science (University of Calcutta, Women's Studies Research Centre), 1990, p.1

[2] Shoma A Chatterji, Gender and Conflict, UBS Publishers' Distributors Pvt. Ltd., New Delhi, 2006, p.1

[3] Bourdieu, P. (1984) Distinction: A Social Critique of the Judgement of Taste, London: Routledge Kegan Paul

[4] Davis, F (1992) Fashion, Culture and Identity, Chicago: University of Chicago Press

[5] Entwistle, J. (2000a) The Fashioned Body: Fashion, Dress and Modern Social Theory, Cambridge: Polity

[6] Entwistle, J (2000b) 'Fashion and the fleshly body: dress as embodies practice' Fashion Theory: The Journal of Dress, Body and Culture, 4, 3, 323-48

[7] Evans, C. and Thornton, M. (1989) Women and Fashion: A New Look, London: Quartet

[8] Simmel, G (1904/ 1971) 'Fashion', On Individuality and Social Forms: Selected Writings, trs D.C.Levine, Chicago: University of Chicago Press

[9] Tseelon, E. (1995) The Masque of Femininity, London: Sage

[10] Veblen, T. (1899/1953) The Theory of the Leisure Class: An Economic Study of Institutions, New York: Mentor

[11] Wilson, E. (1985) Adorned in Dreams: Fashion and Modernity, London: Virago York, P. (1980) Style Wars, London: Sidgwick \& Jackson

[12] Sanghita Sarkar (ed.) (2015), Limiting her sky: Clothing, Body-Politics and Women in Present Day Indian Society, Radiance, Kolkata p.239-245.ISBN 9789381037423 